\section{SCIDoc \\ Publishers}

Infer, Interpret \& Inspire Science

\title{
Magnesium Deficiency Results in Oxidation and Fragmentation of DNA, Down Regulation of Tel- omerase Activity, and Ceramide Release in Cardiovascular Tissues and Cells: Potential Relationship to Atherogenesis, Cardiovascular Diseases and Aging
}

\section{Editorial}

\author{
Altura $\mathrm{BM}^{1,2,3,4,5^{*}}$, Shah $\mathrm{NC}^{1,5}$, Gatha J. Shah ${ }^{1}$, Pérez-Abela $\mathrm{JL}^{6}$, Altura BT ${ }^{1,3,4,5}$ \\ ${ }^{1}$ Department of Physiology and Pharmacology, SUNY Downstate Medical Center, Brooklyn, NY, USA. \\ ${ }^{2}$ Department of Medicine, SUNY Downstate Medical Center, Brooklyn, NY, USA. \\ ${ }^{3}$ Center for Cardiovascular and Muscle Research, SUNY Downstate Medical Center, Brooklyn, NY, USA. \\ ${ }^{4}$ The School of Graduate Studies in Molecular and Cellular Science, State University of New York Downstate Medical Center, Brooklyn, NY, USA. \\ ${ }^{5}$ Bio-Defense Systems, Inc, Rockville Centre, NY, USA. \\ ${ }^{6}$ Instituto Bien de Salud, Lima, Peru.
}

Keywords: Ceramide; Nuclear Factor kB; Proto-Oncogenes; Sphingolipids; Cytokines; p53.

\section{Introduction}

Aging is clearly agreed to be critical in the etiology of metabolic decline in most human subjects as they near their $65^{\text {th }}$ birthday. A great many human subjects at 65 years of age demonstrate clear signs of metabolic and physiological decline, atherosclerosis in most major arteries, high blood pressure, high serum cholesterol levels, diverse cardiovascular diseases, and often type 2 diabetes mellitus, which contribute in major ways to congestive heart failure by their $75^{\text {th }}-85^{\text {th }}$ years. It must be pointed out, here, that all of these aberrations have been shown (or to be associated with) both experimentally and clinically, with the presence of magnesium deficiency $(\mathrm{MgD})$ when they are carefully looked for [1-10].

\section{Magnesium deficiency and cardiovascular diseases}

Disturbances in diet are known to promote lipid deposition and accelerate the growth and transformation of smooth muscle cells in the vascular walls and to promote cardiac dysfunction [3, 9-11]. Several epidemiologic studies in North America and Europe have shown that people consuming Western-type diets are low in magnesium $(\mathrm{Mg})$ content (i.e., 30-65\% of the RDA for $\mathrm{Mg}$ $[8-10,12,13]$; most such diets in the U.S.A. show that $60-80 \%$ of Americans are consuming 185-235 mg/day of $\mathrm{Mg}[8,13]$. In 1900 , in contrast, Americans were consuming 450-550 mg/day of $\mathrm{Mg}[5,8]$. Low $\mathrm{Mg}$ content of drinking water, found in areas of soft-water and $\mathrm{Mg}$-poor soil, is associated with high incidences of atherosclerosis, ischemic heart disease (IHD), coronary vasospasm, hypertension, and sudden-cardiac death (SCD) [2, 5, 8, 14-18]. Both animal and human studies have shown an inverse relationship between dietary intake of $\mathrm{Mg}$ and atherosclerosis [5, 6, 8, 9, 19-21]. The myocardial level of $\mathrm{Mg}$ has consistently been observed to be lower in subjects dying from IHD and SCD in soft-water areas than those in hard-water areas [2, 4-6, 8, 9, 19-21]. $\mathrm{Mg}$ plays essential roles in more than 500 enzymatic reactions in the body and is required for all energy-generating reactions and oxidative phosphorylation [22]. More than 45 years ago, two of us demonstrated that $\mathrm{Mg}^{2+}$ behaves as a natural calcium channel blocker in both cardiac and vascular smooth muscle (VSM) cells [2, 23-26]. We also showed in experimental animals that $\mathrm{Mg}$ behaves as a natural statin in that it can lower blood cholesterol and triglyceride levels as well as act as a powerful vasodilator in the microcirculation and cardiac muscle relaxant $[4,6-8,19$, 27-30]. Hypermagnesemic diets have been shown to ameliorate hypertension and atherogenesis [1-6, 8-10, 19-22, 32-34]. Using sensitive and newly designed specific $\mathrm{Mg}^{2+}$-ion selective electrodes, our laboratories demonstrated that patients with hypertension,

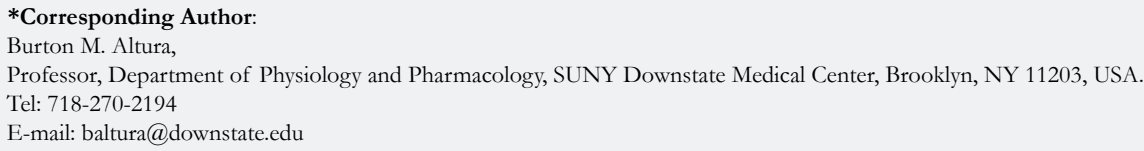

Citation: Altura BM et al., (2016) Magnesium Deficiency Results in Oxidation and Fragmentation of DNA, Down regulation of Telomerase Activity, and Ceramide Release in Cardio vascular Tissues and Cells: Potential Relationship to Atherogenesis, Cardiovascular Diseases and Aging. Int J Diabetol Vasc Dis Res,. 4(1e), 1-5. doi: http://dx.doi.org/10.19070/2328-353X-1600011e

Copyright: Altura $\mathbf{B M}^{\circ}$ 2016. This is an open-access article distributed under the terms of the Creative Commons Attribution License, which permits unrestricted use, distribution and reproduction in any medium, provided the original author and source are credited. 
IHD, cardiac failure, strokes, diabetes types 1 and 2, gestational diabetes, renal-induced vascular changes (associated with elevated serum cholesterol), preeclampsia, hemorrhage, sickle cell anemia in children (and adults), and atherosclerosis exhibit significant reductions in serum/plasma/whole blood levels of ionized, but not total blood levels of $\operatorname{Mg}[5,6,8,34-56]$. Our group has also shown that dietary deficiency in rabbits and rats causes vascular remodeling concomitant with atherogenesis (i.e., arteriolar wall hypertrophy and alterations in the matrices of the vascular walls) and hypertension [4-6, 8, 19, 57-59]. These exciting results have been confirmed, essentially, by other investigators [20, 21, 32, 33]. Some of these results have recently been observed to result in an acceleration of the aging process $[60,61]$. A number of the pathophysiological and molecular-biochemical alterations typically noted in tissues and cells in the aging process have been noted in $\mathrm{MgD}$ tissues and cells recently by our group and some other investigators [4, 6-8, 19, 61-72].

Magnesium deficiency associated with pathophysiological and biochemical alterations characteristic of aging tissues and cells: relationship to telomerases, ceramide, NF-kB and proto-oncogenes

It is well-known that the aging process is associated with elevations in blood/serum/tissue/cell levels of many of the same proinflammatory cytokines and chemokines found in $\mathrm{MgD}$ animals, eg., IL-1, IL-2, IL-6, TNF-alpha, among others [for recent reviews, see [61]]. Reduced levels of telomerases are known to be associated with elevated levels of several cytokines (e.g., TNF-alpha) in a number of aged cell types as well as in serum and cardiovascular tissues and VSM cells of $\mathrm{MgD}$ animals [for recent review, see [61]]; these phenomena being associated with (and correlated to ionized $\mathrm{Mg}$ levels; ceramide generation; and activation of NF-kB and proto-oncogene pathways) [61, 67, $68,74-76]$. It should be pointed out, here, that normal amounts of telomerases in all cell types are required to promote efficient cell cycle kinetics and normal cell growth [77, 78]. $\mathrm{MgD}$ is wellknown to promote disturbances in cell cycle kinetics [79-81] via reactive oxygen and nitrogen species, most likely acting to downregulate telomerases [61]. Several studies have demonstrated that $\mathrm{MgD}$, both in situ and in vitro, cause formation of reactive oxygen (ROS) and nitrogen species (NOS) [5, 6, 8, 61, 63-69]. Interestingly, the increased levels of cellular ROS and NOS were found to be associated with oxidation of DNA and increased levels of the tumor suppressor gene, increased levels of p53 and ceramide, in cardiovascular tissues and cells of $\mathrm{MgD}$ animals [61, 67, 68, 74-76].

\section{Magnesium deficiency causes oxidation of DNA and increased levels of ceramide and p53: possible relation to cellular mutations and epigenetics}

Recently, our laboratories have shown in animals, subjected to 21 days of $\mathrm{MgD}$, that telomerase levels are downregulated and coupled to fragmentation and oxidation of DNA and increased levels of the tumor suppressor gene, p53 $[61,74]$. We believe such data supports the idea that $\mathrm{MgD}$ could lead to multiple mutations in the genomes of multiple cell types found in the initiation of atherogenesis and congestive heart failure. Previous studies from our group [8, 61-64, 67, 68, 74-76, 82, 83], when viewed in the light of these findings, would lend additional support to the hypothesis that mutations and transformations of VSM cells, endothelial cells, and cardiac myocytes caused by $\mathrm{MgD}$, fragmentation of $\mathrm{DNA}$, and oxidation of DNA(all seen in atherogenesis, hypertension, strokes, and congestive heart failure) may play major roles in the aging process, thus leading to multiple cardiovascular changes, including inflammations of the vascular walls, high blood presure (due to formed elemental changes, release of ceramides, release of cytokines, excess wall lipid deposition and peroxidation, etc), cardiac dysfunctions, and eventual cardiac failure.

Several years ago, we suggested that $\mathrm{MgD}$, by itself, probably acts as a genotoxic agent $[74,76]$. As is known, one of ceramide's major pathophysiological actions is its ability to induce cell differentiation and transformation [83-87]. Abnormal cell differentiation, transformation, and growth are pivotal events of atherogenesis, hypertension, and cardiac failure. Hyperplasia and cardiovascular hypertrophy are common events in aging, atherosclerosis, hypertension, and cardiac failure. However, the precise mechanism(s) regulating alterations in tissue mass are not completely understood $[11,87]$. The tumor suppressor protein $\mathrm{p} 53$, ceramide, and telomerases are now known to play key roles in cell transformation, apoptotic events, and the aging process $[11,61,73,77,78]$. Both ceramide and p53 can induce cell cycle arrest (and senescence), induce programmed cell death, and are associated with oxidation and fragmentation of DNA (i.e., genotoxic events) [84-86, 88-91]. $\mathrm{MgD}$ can produce all of these alterations in multiple cell types, including cardiac and VSM cell types [4-6, 8, 59-64, 67, 68, 74-76]. In view of all of these events noted in $\mathrm{MgD}$ animals and cells we would be remiss if some discussion regarding the potential role of epigenetics to magnesium deficiency's long-term effects on the aging process was not pointed out here. All organisms begin as a single cell, which divides through a process of stem cells creating a mass, via a series of carefully-designed changes in gene expression, which is required to form the tissues and cells of the fetal organism. The process of epigenetics orchestrates which genes have to be turned-on in each cell type, and then maintains the particular type of gene expression, or in other words, the particular cell's molecular identity via how DNA encodes the gene. Anything that produces modifications in the chromatin structure can affect a particular gene expression via transcription [92, 93]. Thus, if $\mathrm{MgD}$-states are, indeed, genotoxic as we have suggested [74, 76], then the chromatin structure of one or more cell types (e.g., cardiac, endothelial, or vascular) could be modified and affect one or more genes and cell phenotype, as is found in atherogenesis. DNA methylation, histone modification, and microRNA alterations are known epigenetic pathways. We, thus, believe that prolonged $\mathrm{MgD}$-states should be categorized as another epigenetic mechanism. But, how could all of these irreversible $\mathrm{MgD}$-induced changes be avoided with ease?

\section{Importance of $\mathrm{Mg}$ supplemented drinking water and beverages}

Over the past two-plus decades, our laboratories have been investigating the utility of $\mathrm{Mg}$-supplemented or naturallyoccurring spring waters to avoid the pitfalls of dietary-induced MgD-states [4-6, 8, 19, 37, 47, 61-68, 74-76]. Our results, so far, bolster the idea that water intake (e.g., from tap waters, well waters, bottled waters, beverages using tap/well/spring waters, or desalinated waters) in humans should contain at least 25-40 $\mathrm{mg} /$ liter/day of $\mathrm{Mg}^{2+}[61,68,74-76]$. A number of experiments done in our labs indicate that most, if not all the cardiovascular 
manifestations observed in experimental animals found to be $\mathrm{MgD}$, can be avoided by supplementing drinking waters with appropriate amounts of $\mathrm{Mg}^{2+}$. The latter inclusion in our diets should go a long-way towards the prevention of cardiovascular diseases and ameliorate the aging process of bodily tissues and cells in humans worldwide. Interestingly, on the basis of our work, the World Health Organization has taken our recommendations seriously, for the first time [94].

\section{Conclusions}

There is a growing awareness that dietary deficiency of magnesium is becoming a serious problem, particularly in the Western World. Disturbances in diet are known to promote lipid deposition in the arterial walls and accelerate growth and transformation of smooth muscle cells in vascular walls which are linked to dietary deficiency of magnesium. The myocardial level of $\mathrm{Mg}$ has consistently been observed to be lowered in humans dying from IHD and sudden-cardiac death in soft-water areas than in those people living in hard-water areas. Use of specific $\mathrm{Mg}^{2+}$ ionselective electrodes has been useful, clinically, to reveal serious underlying $\mathrm{Mg}$ - deficient states in patients presenting with various cardiovascular diseases (CVD). $\mathrm{Mg}$ deficiency $(\mathrm{MgD})$ is associated with pathophysiological and biochemical alterations characteristic of aging cells and tissues which are related to upregulation of enzymes in the sphingolipid pathway and release of cytokines, ROS, NOS, activation of NF-kB and proto-oncogenes, resulting in cellular production of free ceramide, p53, and disturbances in cell cycle kinetics of vascular smooth muscle and cardiac muscle cells. The consequences of $\mathrm{MgD}$ lead to oxidation and fragmentation of DNA and inflammation in cells of the cardiovascular system, phenomena characteristic of atherosclerosis, aging, and CVD. We suggest that $\mathrm{MgD}$ states are genotoxic and, thus, one or more cell types (e.g., cardiac, endothelial and/or vascular) could be modified and affect one or more genes and cell phenotype, as is found in atherogenesis, representing epigenetic cell-induced changes. Supplementation of drinking waters (including beverages) is recommended in order to prevent and reduce CVD.

\section{Acknowledgments}

The authors acknowledge that many of our experiments, over almost five decades were supported, in part, by Research Grants from The N.I.H. to BMA and BTA. These included grants from The National Heart, Lung, and Blood Institute; The National Institute on Drug Abuse; The National Institute on Alcoholism and Alcohol Abuse; and The National Institute on Mental Health.

\section{References}

[1]. Seelig MS (1980) Magnesium Deficiency in the Pathogenesis of Disease. Springer US, New York.

[2]. Altura BM, Altura BT (1985) New perspectives on the role of magnesium in the pathophysiology of the cardiovascular system. I. Clinical aspects. Magnesium 4(5-6): 226-244.

[3]. Altura BM, Altura BT (1985) New perspectives on the role of magnesium in the pathophysiology of the cardiovascular system. II. Experimental aspects. Magnesium 4(5-6): 245-271.

[4]. Altura BM, Altura BT (1990) Magnesium and the cardiovascular system: Experimental and clinical aspects updated. Metals in Biological Systems 26: 359-416.

[5]. Altura BM, Altura BT (1995) Magnesium and cardiovascular biology: an important link between cardiovascular risk factors and atherogenesis. Cell Mol Biol Res 41(5): 347-359.
[6]. Altura BM, Altura BT (1995) Magnesium in cardiovascular biology. Sci. Am. Sci Med 2: 28-37.

[7]. Smetana R (1997) Advances in Magnesium Research. John Libbey, London.

[8]. Altura BM, Altura BT (2007) Magnesium: forgotten mineral in cardiovascular biology and angiogenesis. In New Perspectives in Magnesium Research. Springer, New York. 239-260.

[9]. Seelig MS, Rosanoff A (2003) The Magnesium Factor. The Penguin Group, New York.

[10]. Dean C (2014) The Magnesium Miracle. (3rd edtn), Ballantine Books, New York.

[11]. Kumar V, Abbas AK, Aster JC (2015) Robbins and Cotran Pathologic Basis of Disease. (9th edtn), Elsevier Saunders, Philadelphia.

[12]. Ford ES, Mokdad AH (2003) Dietary magnesium intake in a national sample of US adults. J Nutr 133(9): 2879-2882.

[13]. Mosfegh A, Goldman J, Abuja J, Rhodes D, La Comb R (2009) What We Eat in America, NHANES 2005-2006: usual Nurtient Intakes from Food and Water Compared to 1997 Dietary Reference Intakes for Vitamin D, Calcium, Phosphorus, and Magnesium. U.S. Department of Agricultural Research.

[14]. Marier JR, Neri LC (1985) Quantifying the role of magnesium in the interrelationship between human mortality/morbidity and water hardness. Magnesium 4(2-3): 53-59.

[15]. Leary WP (1986) Content of magnesium in drinking water and deaths from ischaemic heart disease in white South Africans. Magnesium 5(3-4): 150153.

[16]. Chipperfield B, Chipperfield JR (1979) Relation of myocardial metal concentration to water hardness and death-rates from ischaemic heart disease. Lancet 2(8145): 709-712.

[17]. Marx A, Neutra RR (1997) Magnesium in drinking water and ischemic heart disease. Epidemiol Rev 19(2): 258-272.

[18]. Rubenowitz E, Molin I, Axelsson G, Rylander R (2000) Magnesium in drinking water in relation to morbidity and mortality from acute myocardial infarction. Epidemiology 11(4): 416-421.

[19]. Altura BT, Brust M, Bloom S, Barbour RL, Stempak JG, et al. (1990) Magnesium dietary intake modulates blood lipid levels and atherogenesis. Proc Natl Acad Sci USA 87(5): 1840-1844.

[20]. Ouchi Y, Tabata RE, Stegiopoulos K, Sato K, Hatori A, et al. (1990) Effect of dietary magnesium on development of atherosclerosis in cholesterol-fed rabbits. Arteriosclerosis 10(5): 732-737.

[21]. King JL, Miller RJ, Blue JP Jr, O'Brien WD Jr, Erdman JW Jr (2009) Inadequate dietary magnesium intake increases atherosclerotic plaque development in rabbits. Nutr Res 29(5): 343-349.

[22]. de Baaij JHF, Hoenderop JG, Bindels RJ (2015) Magnesium in man: Implications for health and disease. Physiol Rev 95(1): 1-46.

[23]. Altura BM, Altura BT (1971) Influence of magnesium on drug-induced contractions and ion content in rabbit aorta. Am J Physiol 220: 938-944.

[24]. Altura BM, Altura BT (1974) Magnesium and contraction of arterial smooth muscle. Microvasc Res 7(2): 145-155.

[25]. Altura BM, Altura BT (1981) Role of magnesium ions in contractility of blood vessels and skeletal muscles. Magnesium Bulletin 3(1a): 102-114.

[26]. Altura BM, Altura BT (1981) General anesthetics and magnesium ions as calcium antagonists. In: New Perspectives on Calcium Antagonists. Am Physiol Soc 131-145.

[27]. Altura BM, Altura BT (1978) Magnesium and vascular tone and reactivity. Blood Vessels 15: 5-16.

[28]. Friedman HS, Nguyen TN, Mokraoui AM, Barbour RL, Murakawa T, et al. (1987) Effects of magnesium chloride on cardiovascular hemodynamics in the neurally intact dog. J Pharmacol Exp Ther 243(1): 126-130.

[29]. Nagai I, Gebrewold A, Altura BT, Altura BM (1988) Magnesium salts exert direct vasodilator effects on rat cremaster muscle microcirculation. Arch Int Pharmacodyn Ther 294: 194-214.

[30]. Nishio A, Gebrewold A, Altura BT, Altura BM (1988) Comparative effects of magnesium salts on reactivity of arterioles and venules to constrictor agents. An in situ study on microcirculation. J Pharmacol Exp Ther 246(3): 859-865.

[31]. Nishio A, Gebrewold A, Altura BT, Altura BM (1989) Comparative vasodilator effects of magnesium salts on rat mesenteric arterioles and venules. Arch Int Pharmacodyn Ther 298: 139-163.

[32]. Luthringer C, Rayssiguier Y, Gueux E, Berthelot A (1988) Effect of moderate magnesium deficiency on serum lipids, blood pressure and cardiovascular reactivity in normotensive rats. Br J Nutr 59(2): 243-250.

[33]. Saris NE, Mervaala E, Karppanen H, Khawaja JA, Lewenstam A (2000) Magnesium: an update on physiological, clinical and analytical aspects. Clin Chim Acta 294(1-2): 1-26.

[34]. Altura BT, Altura BM (1991) Measurement of ionized magnesium in whole blood, plasma and serum with a new ion-selective electrode in healthy and diseased human subjects. Magnes Trace Elem 10(2-4): 90-98. 
[35]. Altura BT, Shirey TL, Young CC, Hiti J, Dell'Orfano K, et al. (1992) A new method for the rapid determination of ionized $\mathrm{Mg}^{2+}$ in whole blood, serum and plasma. Methods Find Exp Clin Pharmacol 14(4): 297-304.

[36]. Handwerker SM, Altura BT, Royo B, Altura BM (1993) Ionized magnesium and calcium levels in umbilical cord serum of pregnant women with transient hypertension during labor. Am J Hypertens 6(6 Pt 1): 542-545.

[37]. Altura BM, Altura BT (1994) Role of magnesium and calcium in alcoholinduced hypertension and strokes as probed by in vivo television microscopy, digital image microscopy, optical spectroscopy, 31P-NMR spectroscopy and a unique magnesium ion-selective electrode. Alcohol Clin Exp Res 18(5): 1057-1068.

[38]. Markell MS, Altura BT, Barbour RL, Altura BM (1993) Ionized and total magnesium levels in cyclosporin-treated renal transplant recipients: relationship with cholesterol and cyclosporin levels. Clin Sci 85(3): 315-318.

[39]. Markell MS, Altura BT, Sarn Y, Delano BG, Hudo O, Friedman EA, Altura BM (1993) Deficiency of Serum ionized magnesium in patients receiving hemodialysis or peritoneal dialysis. ASAIO J 39(3): M801-M804.

[40]. Resnick LM, Altura BT, Gupta RK, Alderman MH, Altura BM (1993) Intracellular and extracellular magnesium depletion in type 2 diabetes (noninsulin-dependent) diabetes mellitus. Diabetologia 36(8): 767-770.

[41]. Altura BM, Lewenstam A (1994) Preface to the First International Workshop on Unique Magnesium-Sensitive Ion Selective Electrodes. Scand J Clin Lab Invest 54(suppl 217): 2.

[42]. Altura BM, Altura BT (1996) Role of magnesium in pathophysiological processes and the clinical utility of magnesium ion-selective electrodes. Scand J Clin Lab Invest 56(Suppl 224): 211-234.

[43]. Bardicef M, Bardicef O, Sorokin Y, Altura BM, Altura BT, et al. (1995) Extracellular and intracellular magnesium depletion in pregnancy and gestational diabetes. Am J Obst Gynecol 172(3): 1009-1013.

[44]. Altura BT, Memon ZI, Zhang A, Cracco RQ, Altura BM (1997) Low levels of serum ionized magnesium found in patients early after stroke which result in rapid elevation in cytosolic free calcium and spasm in cerebral vascular smooth muscle cells. Neurosci Lett 230(1): 37-40.

[45]. Resnick LM, Bardicef D, Altura BT, Alderman MH, Altura BM (1997) Serum ionized magnesium: Relation to blood pressure and racial factors. Am J Hypertens 10(12 Pt 1): 1420-1424.

[46]. Seelig MS, Altura BM (1997) How best to determine magnesium requirement: Need to consider cardiotherapeutic drugs that affect its retention. J Am Coll Nutr 16(1): 4-6.

[47]. Altura BM, Altura BT (1999) Association of alcohol in brain injury, headaches and stroke with brain tissue and serum levels of ionized magnesium: A review of recent findings and mechanisms of action. Alcohol 19(2): 119-130.

[48]. Muneyyrici-Delale O, Nacharaju VL, Jalou S, Rahman M, Altura BM, et al. (2001) Divalent cations in women with PCOS: implications for cardiovascular disease. Gynecol Endocrinol 15(3): 198-201.

[49]. Handwerker SM, Altura BT, Jones KY, Altura BM (1995) Maternal-fetal transfer of ionized serum magnesium during stress of labor and delivery: a human study. J Am Coll Nutr 14(4): 376-381

[50]. Scott VL, DeWolf AM, Kang Y, Altura BT, Virji MA, et al. (1996) Ionized hypomagnesemia in patients undergoing orthotopic liver transplantation: a complication of citrate intoxication. Liver Transpl Surg 2(5): 343-347.

[51]. Fogh-Andersen N, Altura BM, Altura BT, Siggaard-Andersen O (1996) Changes in plasma ionized calcium and magnesium in blood donors after donation of $450 \mathrm{ml}$ blood. Effects of hemodilution and Donnan equilibrium. Scand J Clin Lab Invest 56(Suppl 224): 245-250.

[52]. Djurhuus S, Henriksen JE, Klitgaard NA, Blaabjerg O, Thye-Ron P, et al. (1999) Effect of moderate improvement in metabolic control on magnesium and lipid concentrations in patients with type I diabetes. Diabetes Care 22(4): 546-554

[53]. Djurhuus S, Klitgaard NA, Pedersen KK, Blaabjerg O, Altura BM, et al. (2001) Magnesium reduces insulin-stimulated glucose uptake and serum lipid concentrations in type I diabetes. Metabolism 50(12): 1409-1417.

[54]. Altura RA, Wang WC, Wynn L, Altura BM, Altura BT (2002) Hydroxyurea therapy associated with declining serum levels of magnesium in children with sickle cell anemia. J Pediatr 140(5): 565-569.

[55]. Zehtabchi S, Sinert R, Rinnert S, Chang B, Hennis R, et al. (2004) Serum ionized magnesium levels and ionized calcium to magnesium ratios in adult patients with sickle cell anemia. Am J Hematol 77(3): 215-222.

[56]. Apostol A, Apostol R, Ali E, Choi A, Ehsuni N, et al. (2010) Cerebral spinal fluid and serum ionized magnesium and calcium levels in preeclamptic women during administration of magnesium sulfate. Fertil Steril 94(1): 276282

[57]. Altura BM, Altura BT, Gebrewold A, Ising H, Gunther T (1984) Magnesium deficiency and hypertension: correlation between magnesium deficiency diets and microcirculatory changes in situ. Science 223(4642): 1315-1317.

[58]. Altura BM, Altura BT, Gebrewold A, Gunther T, Ising H (1992) Noiseinduced hypertension and magnesium: relationship to microcirculation and calcium. J Appl Physiol 72(1): 194-202

[59]. Altura BM, Altura BT (1996) Magnesium as an extracellular signal in cardiovascular pathobiology. J Jap Soc Magnes Res 15: 17-32.

[60]. Killilea DW, Ames BN (2008) Magnesium deficiency accelerates cellular senescence in cultured human fibroblasts. Proc Natl Acad Sci USA 105(15) 5768-5773.

[61]. Shah NC, Shah GJ, Li Z, Jiang XC, Altura BT, et al. (2014) Short-term magnesium deficiency downregulates telomerase, upregulates neutral sphingomyelinase and induces oxidative DNA damage in cardiovascular tissues: relevance to atherogenesis, cardiovascular diseases and aging. Int J Clin Exp Med 7(3): 497-514.

[62]. Altura BM, Gebrewold A, Altura BT, Brautbar N (1996) Magnesium depletion impairs myocardial carbohydrate and lipid metabolism and cardiac bioenergetics and raises myocardial calcium content in-vivo: relationship to etiology of cardiac diseases. Biochem Mol Biol Int 40(6): 1183-1190.

[63]. Wu F, Altura BT, Gao J, Barbour RL, Altura BM (1994) Ferrylmyoglobin formation induced by acute magnesium deficiency in perfused rat heart causes cardiac failure. Biochim Biophys Acta 1225(2): 158-164.

[64]. Altura BM, Gebrewold A, Zhang A, Altura BT (2003) Low extracellular magnesium ions induces lipid peroxidation and activation of nuclear factor$\mathrm{kB}$ in canine cerebral vascular smooth muscle: possible relation to traumatic brain injury and strokes. Neurosci Lett 341(3): 189-192.

[65]. Dickens BF, Weglicki WB, Li YS, Mak IT (1992) Magnesium deficiency in vitro enhances free radical-induced intracellular oxidation and cytotoxicity in endothelial cells. FEBS Lett 311(3): 187-191

[66]. Weglicki WB, Mak IT, Kramer JH, Dickens BF, Cassidy MM, et al. (1996) Role of free radicals and substance $\mathrm{P}$ in magnesium deficiency. Cardiovasc Res 31(5): 677-682.

[67]. Altura BM, Kostellow AB, Zhang A, Li W, Morrill GA, et al. (2003) Expression of the nuclear factor- $\mathrm{kB}$ and proto-oncogenes $\mathrm{c}-\mathrm{fos}$ and $\mathrm{c}$-jun are induced by low extracellular $\mathrm{Mg}^{2+}$ in aortic and cerebral vascular smooth muscle cells: possible links to hypertension, atherogenesis, and stroke. Am J hypertens 16(9 Pt1): 701-707.

[68]. Altura BM, Shah NC, Jiang XC, Li Z, Perez-Albela JL, et al. (2009) Shortterm magnesium deficiency results in decreased levels of serum sphingomyelin, lipid peroxidation, and apoptosis in cardiovascular tissues. Am J Physiol Heart Circ Physiol 297(1): H86-H92.

[69]. Mazur A, Maier JA, Rock E, Gueux E, Nowacki W, et al. (2007) Magnesium and the inflammatory response: potential physiopathological implications. Arch Biochem Biophys 458(1): 48-56.

[70]. Emila S, Swaminathan S (2013) Role of magnesium in health and disease. J Exp Sci 4(2): 32-43.

[71]. Long S, Romani AM (2014) Role of cellular magnesium in human diseases. Austin J Nutr Food 2(10).

[72]. Grober U, Schmidt J, Kisters K (2015) Magnesium in prevention and therapy. Nutrients 7(9): 8199-8226.

[73]. Neves D (2015) Anti-Ageing Nutrients. Evidence-based Prevention of AgeAssociated Diseases. Wiley Blackwell, Oxford.

[74]. Altura BM, Shah NC, Li Z, Jiang XC, Zhang A, et al. (2010) Short-term magnesium deficiency upregulates sphingomyelin synthase and p53 in cardiovascular tissues and cells: relevance to de novo synthesis of ceramide. Am J Physiol Heart Circ Physiol 299(6): H2046-H2055.

[75]. Altura BM, Shah NC, Shah GJ, Zhang A, Li W, et al. (2014) Short-term $\mathrm{Mg}$-deficiency upregulates protein kinase $\mathrm{C}$ isoforms in cardiovascular tissues and cells; relation to NF-kB, cytokines, ceramide salvage sphingolipid pathway and PKC-zeta: hypothesis and review. Int J Clin Exp Med 7(1): $1-21$.

[76]. Altura BM, Shah NC, Shah G, Zhang A, Li W, et al. (2012) Short-term magnesium deficiency upregulates ceramide synthase in cardiovascular tissues and cells: cross-talk among cytokines, $\mathrm{Mg} 2+, \mathrm{NF}-\mathrm{kB}$ and de novo ceramide. Am J Physiol Heart Circ Physiol 302(1): H319-H332.

[77]. Dong CK, Mastomi K, Hahn WC (2005) Telomerase: regulation, function and transformation. Crit Rev Oncol Hematol 54(2): 85-93.

[78]. Masutomi K, Yu EY, Khurts S, Ben-Porath I, Currier JL, et al. (2003) Telomerase maintains telomere structure in normal human cells. Cell 114(2): 241-253.

[79]. Rubin H (1982) Differences in growth requirement and retentiveness for magnesium in non-transformed and transformed mouse 3T3 cells. Magnesium 1: 41-48.

[80]. Walker GM (1986) Magnesium and cell cycle control: an update. Magnesium 5(1): 9-33.

[81]. Vernon WB (1988) The role of magnesium in nucleic acid and protein metabolism. Magnesium 7(5-6): 234-248.

[82]. Altura BM, Shah NC, Shah GJ, Perez-Albela JL, et al. (2016) Insights into the possible mechanisms by which platelet-activating factor and PAF-receptors function in vascular smooth muscle in magnesium deficiency and vascular remodeling: possible links to atherogenesis, hypertension and cardiac 
failure. Int J Cardiol Res 3(1e): 1-3.

[83]. Haimovitz-Friedman A, Kolesnick RN, Fuks Z (1997) Ceramide signaling in apoptosis. Br Med Bull 53(3): 539-553.

[84]. Hannun YA, Obeid LM (2002) The ceramide-centric universe of lipidmediated cell regulation: stress encounters of the lipid kind. J Biol Chem 277(29): 25847-25850.

[85]. Andrieu-Abadie N, Gouaze V, Salvayre R, Levade T (2001) Ceramide in apoptosis signaling: relationship with oxidative stress. Free Radic Biol Med 31(6): 717-728.

[86]. Auge N, Negre-Salvayre A, Salvayre R, Levade T (2000) Sphingomyelin metabolites in vascular signaling and atherosclerosis. Prog Lipid Res 39(3): 207-239.

[87]. Intengan HD, Schiffrin EL (2001) Vascular remodeling in hypertension: roles of apoptosis, inflammation, and fibrosis. Hypertension $38(3 \mathrm{Pt} 2)$ : 581-587.
[88]. Andreassi M (2003) Coronary atherosclerosis and somatic mutations: an overview of the contributive factors for oxidative DNA damage. Mutat Res 543(1): 67-86.

[89]. Mercer J, Mahmoudi M, Bennett M (2007) DNA damage, p53, apoptosis and vascular disease. Mutat Res 621(1-2): 75-86.

[90]. Meek DW (2009) Tumor suppression by p53: a role for the DNA dammage response? Nat Rev Cancer 9: 714-723.

[91]. Vousden KH, Ryan KM (2009) p53 and metabolism. Nat Rev Cancer 9(10): 691-700.

[92]. Katada S, Imhof A, Sassone-Corsi P (2012) Connecting threads: Epigenetics and metabolism. Cell 148(1-2): 24-28.

[93]. Lu C, Thompson CB (2012) Metabolic regulation of epigenetics. Cell Metab 16(1): 9-17.

[94]. World Health Organization (2009) Calcium and Magnesium in Drinking Water. WHO Publications, Geneva. 